Research Article

\title{
The emergence of a Social Innovation Ecosystem in Portugal: An exploratory approach based on the perspective of strategic stakeholders
}

\section{La emergencia de un Ecosistema de Innovación Social en Portugal: Un enfoque exploratorio basado en la perspectiva de los actores estratégicos}

\author{
Hugo Pinto ${ }^{*}$, Silvia Ferreira ${ }^{2}$ and Jorge André Guerreiro ${ }^{3}$ \\ ${ }^{1}$ Centre for Social Studies, University of Coimbra \& Faculty of Economics, University of Algarve. \\ 2 Faculty of Economics, University of Coimbra \& Centre for Social Studies, University of Coimbra. \\ ${ }^{3}$ Centre for Social Studies, University of Coimbra. \\ *Correspondence: hpinto@ces.uc.pt
}

\begin{abstract}
The concept of ecosystem has been used to describe a dynamic set of relationships, services and interdependencies that potentiate the creation, renewal and growth of organizations. Social innovation is largely influenced by ecosystem conditions. The Portuguese social innovation ecosystem is a particularly interesting case study, as it assumes a hybrid structure that expresses a variety of policy schemes, networks and support structures. This article debates the concept of social innovation ecosystem and presents an exploratory approach to its mapping. Based on interviews with strategic stakeholders in the social and solidarity economy and social enterprises, the study elaborates on the specificities of the social innovation ecosystem. The Portuguese ecosystem is comprised of three sub-ecosystems that show different weights, limited connections and overlapping: social economy, social business, and the social solidarity ecosystem. The article concludes with an overview of the current state of social innovation, emphasizing the perspectives of stakeholders on recent experiences that the Portuguese state has developed in establishing dialogue within organizations integrating social innovation dynamics.
\end{abstract}

Keywords: social innovation; ecosystems; complexity; social economy; social enterprises.

Resumen: El concepto de ecosistema se ha utilizado para describir un conjunto dinámico de relaciones, servicios e interdependencias que potencian la creación, la renovación y el crecimiento de las organizaciones. La innovación social se ve influida en gran medida por las condiciones del ecosistema. El ecosistema portugués de innovación social es un caso de estudio particularmente interesante, ya que asume una estructura híbrida que expresa una variedad de esquemas políticos, redes y estructuras de apoyo. Este artículo debate el concepto de ecosistema de innovación social y presenta un enfoque exploratorio para su mapeo. A partir de entrevistas con actores estratégicos de la economía social y solidaria y con empresas sociales, el estudio profundiza en las especificidades del ecosistema de innovación social. 
El ecosistema portugués se compone de tres sub-ecosistemas que muestran un peso diferente, conexiones limitadas y solapamientos: la economía social, la empresa social y el ecosistema de la solidaridad social. El artículo concluye con una visión general del estado actual de la innovación social, haciendo hincapié en las perspectivas de las partes interesadas sobre las recientes experiencias que el Estado portugués ha desarrollado para establecer el diálogo dentro de las organizaciones que integran la dinámica de la innovación social.

Palabras clave: innovación social; ecosistemas; complejidad; economía social; empresas sociales.

\section{Introduction}

Social innovation (SI) is a relatively old concept that attained a considerable degree of popularity over the last decade and a half (Nicholls \& Ziegler, 2019; Godin, 2012). It is a different take on the concept of innovation (or a return to its roots, to be more precise) since it focuses on the social aspects and ends of innovation. More recently, Social Innovation Ecosystem (SIE) has garnered some interest by social innovation scholars, who find value and usefulness in using the ecosystem metaphor as a way to highlight the complex dimensions of the social innovation concept (Granstrand \& Holgersson, 2019).

As one of the first countries to adopt social innovation into public policies and create a dedicated financing program to foster social innovation in the aftermath of the 2008 crisis, Portugal can provide useful information for other countries attempting to enact similar policies. This is more so the case when we consider the country's recent democratization (in 1974) and the weight that social organizations have in a considerable portion of its population. Some of these social organizations have existed for centuries and remain important to the present day. One of the emerging questions regard the meaning of the recent evolution of the social innovation landscape, with the implementation of new policies and consolidation of new (types of) players. Can this change be associated with the existence of a Social Innovation Ecosystem?

This article seeks to answer to this research question, reviewing recent changes in the Portuguese SIE, analyzing this process through the lens of complexity. We understand SIE as an inherently complex, multi-dimensional social system, that comprises several subsystems and a plethora of diverse actors and organizations. We attempt to understand the changes from the plurality of points of views shown by several stakeholders and identify the shortcomings, problems and tensions that have arisen from new policies enacted in recent years.

The analysis presents data collected from interviews conducted with major key players and stakeholders in the Portuguese SIE. Main findings are presented in a descriptive manner, detailing what issues and struggles the interviewees face and how they can be understood as part of larger transformations in the Portuguese SIE in the aftermath of the 2008 crisis.

\section{Social Innovation Ecosystems}

\subsection{What is Social Innovation?}

Social innovation designates a different set of phenomena when compared to the strict concept of innovation, more commonly applied to technological or economic innovation, even if originally referred exclusively to social phenomena as well (Godin, 2015). While all forms of innovation aim to produce improvements and create value that ultimately has a positive effect on society as a whole, SI aims to satisfy needs that are not addressed by the market, while promoting social inclusion and transforming social and power relations (Noya, 2011).

As western Europe faced an unemployment crisis during the late 70s through the 90s, many countries experienced difficulties dealing with social problems surfacing at this period (Kerlin, 2006). At the same period, neoliberal ideas became prominent in power circles and governments 
progressively laxed social protection legislation and workers' rights, deregulated markets and promoted the privatization of previously protected sectors of the economy (Schneider, 2014), culminating in what has been described as the beginning of the "crisis of the welfare state" (Habermas, 1986). This crisis led to decentralization, privatization and reduction of services offered by the State, aggravating the already fragile conditions of many citizens. These increasing needs paved the way for the emergence of different types of social responses that filled those gaps (Kerlin, 2006). It is in this context that SI emerged as a possible solution for existing and emerging challenges in society, becoming a prominent subject from the 2000s onwards (Moulaert, MacCallum \& Hillier, 2013; Moulaert \& MacCallum, 2019).

SI as a subject of research gained popularity from the 90 s onwards by being employed in studies dealing with novel social problems, such as how innovation can lead to social change through social movements, new forms of social relations and new approaches to social problems (cf. Ayob, Teasdale \& Fagan, 2016). Some authors go as far as to consider it a new socially recognized solution (product and process), implying collective action, that aims and generates social change with three attributes: satisfaction of human needs, promotion of social inclusion and empowerment, allowing for the transformation of power relations (André \& Abreu, 2006; Moulaert, MacCallum \& Hillier, 2013).

With such promise, SI became regularly featured in research, having attained great popularity in public spheres, policy making and with supranational organizations (McGowan, Westley \& Tjornbo, 2017). Unfortunately, this rapid growth was not accompanied by a conceptual maturation, resulting from the fact that research about SI has been "largely based on anecdotal evidence and case studies lacking unifying paradigms", and build upon technological innovation knowledge that, to this day, still dominates innovation research (Van Der Have \& Rubalcaba, 2016), without repositioning itself or creating a specific paradigm to this effect (Cajaiba-Santana, 2013:42).

The fact that SI research is particularly interdisciplinary - and has been so since its earliest usages (cf. Taylor, 1970) - has also contributed to some of the difficulties with the concept's development, as the different disciplinary traditions manifest into different approaches that don't always dialogue with each other, thus contributing to a fragmented landscape of SI research (Moulaert, MacCallum \& Hillier, 2013).

SI is a complex phenomenon, as it involves a variety of actors in complex and dynamic relationships and interdependencies. But this is also what allows it to effectively address complex problems that defy conventional solutions, as it is not a standard formula or linear process, but rather quite adaptable to new circumstances.

It should come to no surprise that SI was heavily influenced by complexity theory, given that it began to grow theoretically in the early years of the 2000s (Moulaert \& MacCallum, 2019), around the same time that evolutionary, adaptative and complexity were becoming crucial ideas in innovation literature (Floysand \& Jakobsen, 2010). But even more so, complexity sciences became interested in social problems as they became more intricate and complex in their nature - or perhaps when science became aware that social problems were far harder to deal with than what had been thought for decades. SI gained popularity for the same reason: the end of the XX century was marked by the realization that complex social phenomena were becoming ever more common and the usual solutions were no longer valid, which also meant that social theory itself had to adapt to this brave new world (Strasser, Kraker \& Kemp, 2020; Asenova \& Damianova, 2019).

In Portugal, the term SI gained visibility after the 2008 crisis, mainly to describe transformations and new dynamics in the social and solidarity economy, as well as the emergence of a new wave of social enterprises and social entrepreneurs. The emergence of social enterprises and other non-profit organizations that offer social services with or instead of the State to answer social needs is rather recent and is still in a development phase. The 2008 economic crisis accelerated this process, but also saw the State implementing cutbacks in public spending on 
welfare services and to social organizations. Recently, in the framework of the European Structural and Investments Funds 2014-2020, the Portuguese government launched an initiative - Portugal Inovação Social (Portugal Social Innovation) -, especially oriented to finance the social innovation-related organizations and to create the necessary framework conditions to generate a SI ecosystem in the country.

\subsection{Complexity and Innovation}

Complexity is a defining characteristic of current societies. Complexity is, of course, not something conceived in these last few years nor a novelty of our age - it has been ever-present in human civilizations in one form or another. What is novel is the sheer level of complexity we find in our world today, in no small part due to innovation (whether technological, social or of any other kind) and globalization (Turner \& Baker, 2019). This pace of change hitherto unknown has greatly affected our ability to predict and anticipate what is to follow, something that has had a profound impact on how organizations operate. Concurrently, the need to deal with a greater amount of information and dominate a larger number of skills to be effective at one's task is equally representative of these transformations that highlight the growing complexity of the dynamic social world. It is a process of complexification that affected businesses, governance, research or media (Williams, 2020).

Complexity theory seeks to make sense of complex systems made up of interdependent heterogeneous and adaptative agents and processes that interact, learn and affect each other (Campbell-Hunt, 2007; Borzillo \& Kaminska-Labbe, 2011). The key premise of complexity theory is that the whole is different from the sum of its individual parts, thus meaning that we cannot understand a complex system by looking at its individual parts and attempt to extrapolate from the fragments to the whole (Richardson, 2004).

Much of the recent developments in complexity theory stem from acknowledging the contributions of theoretically proximate fields, such as systems theory, complex adaptive systems, as all these fields delve into similar phenomena, share a similar language and are concerned with the complex relations and dynamic properties that define the current world (Turner \& Baker, 2019). The interdisciplinary character of complexity theory (Cairney \& Geyer, 2017) is also shown by its recent popularity with mixed-methods approaches, something that reflects the diverse disciplinary roots of complexity theory and explains how the theory grew with such wide range of contributions (Kallemeyn, Hall \& Gates, 2020), from physics, biology, social sciences or cybernetics, to name but a few.

Of particular interest to this article is the usage of complexity as a means to identify issues in innovation policy that can act as barriers to innovation (Frenken, 2017). As an inherently complex system, a national innovation system is the product of different elements: laws, regulations, organizations, social actors and macro-phenomena that can exert an external pressure on the system, such as economic crisis, pandemics or disruption in supply chains (Bristow \& Healy, 2018). In less abstract terms, were we to consider this landscape as an innovation ecosystem, one would thus be able to identify vulnerabilities and possibilities for its disruption, especially with innovation becoming more interactive, collaborative and multidirectional (Russell \& Smorodinskaya, 2018).

Recent advances in complexity theory, especially that which intersects complex adaptive systems theory, stress the potential of innovation in crisis resistance and recovery, thus sharing a similar position to regional economic resilience (Bristow \& Healy, 2017). Both theories hold the view that the complexity arises from relations, interactions and the interconnectivity of the elements that comprise the system and between the system and the larger environment, which relates closely to the ecosystem metaphor that stresses however smaller elements or subsystems may affect the whole and create disruptions that vary in severity depending on the system's resilience or adaptive capacity (Cooke, 2012). 
This line of research has garnered some popularity within evolutionary economic geography, especially in the aftermath of the 2008 crisis - both in the search for explanations for why it affected regions so differently and how the post-crisis policies prompted transformations at a territorial (regional) level, with complexity becoming an important asset for these studies (cf. Martin \& Sunley, 2010). Equally relevant is the concept of panarchy i.e., how a healthy system can experiment and seek to improve from innovations while avoiding negative effects that destabilize it (Holling, 2001). Indeed, the theoretical proximity between complexity theory, complex adaptive systems, resilience theory and panarchy theory have been known for over a decade and there are many examples of fruitful research that combine and intersect these theoretical fields (Germestani, Allen \& Gunderson, 2009; Moore \& Westley, 2011).

\subsection{Social Innovation Ecosystems}

Although the usage of ecological concepts in management and organizational theory dates as far back as the early 1950s (Durst \& Poutanen, 2013), and in social sciences to the mid XIX century, the concept of innovation ecosystem has a much shorter history. According to the Oxford English Dictionary, in ancient Greek, the word sústēma meant a "whole made of several parts or members", referring to musical scales and how the different notes combined and arranged would produce a set of melodies and tunes. Later, the Romans would use systēma much in the same way and the word passed down through the scholastic tradition and make its way into the English language.

In the late XIX century, with the development of power engineering and the growing complexity of the industrial machines, the word system was reintroduced, as these constructs could better be described as a system made of several, smaller machines, parts and components that worked together to deliver a specific function only attainable by their particular arrangement (Bertalanffy, 1968). After the 1940s, biology would influence physiology, information theory and cybernetics, and something resembling a theory of systems would begin to develop, with contributions from all these fields (Stichweh, 2011).

Influenced by this movement in the natural sciences, sociology renewed its interest in systems (Castellani \& Hafferty, 2009), with the influential Talcott Parsons (1951) outlining an approach to the analysis of the structure and processes of social systems. This line of thinking would be further developed by Niklas Luhmann (1995) but focusing on the idea that systems processed complexity and information, several years after the decline in popularity that systems theory experienced in the social sciences, by the late 1960s, partly due to a rejection of Parsonian structural functionalism and the emergence of micro and meso level, actor-centered competing social theories.

Nonetheless, disciplines such as management and economics would continue on using the term system in their theories (Vancouver, 2013). In sociology, on the other hand, the complex systems approach developed into complex networks analysis, sociocybernetics, new social systems theory, computational sociology and the British school of complexity (Castellani \& Hafferty, 2009). The concept of ecosystem was coined in ecology by Tansley (1935), in an attempt to make sense of how plant communities both affect and are affected by their environment. The existence of these communities was explained by concepts such as evolution, competition, predation and mutualism, and the flows of material and energy, as well as connections and flows (Shaw \& Allen, 2018). Thus, the ecosystem concept not only predates systems theory, but was also part of the focus on systems by biology that would popularize the term system in the following years (Stichweh, 2011). An example of the influence that biology held over systems theory can be show by Luhmann (1974), who borrowed the term ecological dominance to describe the capacity of a given system to influence other systems through its higher degree of organized complexity and flexibility.

But biology's influence would be felt in other domains of social theory as well. In 1993, Moore introduced the concept of ecosystem to management studies, suggesting that companies 
should be viewed as "not as a member of a single industry but as part of a business ecosystem that crosses a variety of industries." (Moore, 1993: 76). He argued further that "in a business ecosystem, companies co-evolve capabilities around a new innovation: they work cooperatively and competitively to support new products, satisfy customer needs, and eventually incorporate the next round of innovations." (op. cit.).

While Moore's analogy would feature in some articles in the following years, it would not be until late 2007 that the subjects of innovation ecosystem and business ecosystem would recurrently feature in scientific papers and business publications (Gomes, Facin, Salerno \& Ikenami, 2018). Since then, ecosystem saw its way into thousands of scientific and research materials, who found that the term, in the sense that Tansley gave it, could be used as a metaphor to "evoke and highlight interdependencies between organizations and to provide a fresh way to think about specialization, co-evolution, and co-creation of value" (Thomas \& Autio, 2012: 2).

The concept is increasingly being used in management and business to describe "(...) collectives of heterogeneous, yet complementary organizations who jointly create some kind of system-level output, analogous to an 'ecosystem service' delivered by natural ecosystems, and one that extends beyond the outputs and activities of any individual participant of the ecosystem" (Thomas \& Autio, 2020: 2). These authors underline the common attributes of ecosystems: participant variety (meaning that ecosystems are composed of heterogeneous participants with various roles), systemic services (ecosystems facilitate an output that is more encompassing than any single participant could deliver alone), interdependence (strong linkages, reciprocity, trust and social capital, among ecosystem participant), and non-contractual governance (which relies primarily on non-market mechanisms and institutions, such as role definition, complementarities, co-design and co-alignment).

In his seminal article, Adner, taking inspiration in Moore's previous usage of ecosystem, combined it with innovation to create his concept of innovation ecosystem, which he defined as "the collaborative arrangement through which firms combine their individual offerings into a coherent, customer-facing solution" (Adner, 2006: 99). This concept, although close to that of business ecosystem (Moore, 1993), became more popular than its predecessor in the following years, coming close to replacing it altogether, even if some authors have yet still to agree on whether the concepts are synonymous or have quite different meanings (cf. Gomes, Facin, Salerno \& Ikenami, 2018).

The concept of innovation ecosystem would prove itself appealing, particularly to policymakers and would widen its scope in relation to its predecessor. The concept was used in macro, meso and micro approaches to innovation, since "an ecological system of innovation can be constructed at a number of levels of abstraction and detail - from an individual technology project, to the enterprise, to the industry sector, to the national, regional and even global level" (Yawson, 2009: 4) and thus prove to be more adaptable to different contexts and situations.

It is also relevant to underline that there are different kinds of ecosystems and that a given ecosystem can have several sub-ecosystems. Recently Thomas and Autio (2020) have identified significant overlap in the use of the concepts of innovation ecosystems, business ecosystems, technology ecosystems, platform ecosystems, entrepreneurial ecosystems and knowledge ecosystems. As such, it is paramount to clearly identify the specific subset of the ecosystem chosen and clearly delimitate what is part of it.

Over the last few years, some authors began questioning if the eco prefix in innovation ecosystem added anything new to the innovation system paradigm. These criticisms focused mostly on how one could easily replace ecosystem with system in journal articles and policy reports, and get the same exact result, without any loss of intelligibility, since "these contributions do not depend on the eco-prefix, and their eco-pretensions are metaphorical rather than rigorous" (Oh, Phillips, Park \& Lee, 2016: 2). The conceptual fragmentation of ecosystem is visible in two main aspects (Thomas \& Autio, 2020). First, the fact that the ecosystem concept, broadly speaking, can be applied at different spatial levels (suburban, city, regional, to national and global) and 
types of 'units' of analysis (a focal firm, a cluster, platforms, and even entire industries). Secondly, the nature of the 'ecosystem services' or ecosystem outputs collectively generated can be very different. This means that ecosystems can be inserted in many broad categories, depending in their ecosystem output: knowledge ecosystem if the focus is the creation of new knowledge, business ecosystem if the goal is the creation and improvement of firms, or innovation ecosystem, should one be focused on the creation of innovations (Valkokari, 2015).

Today, after several noteworthy contributions (Gomes et al., 2018; Granstrand \& Holgersson, 2019; Oh, Phillips, Park \& Lee, 2016; Ritala \& Almpanopoulou; Thomas \& Autio, 2012), it has become clear that the concept of innovation ecosystem has grown faster than it has matured, considering that many authors use flawed definitions that at no point distinguish themselves from the concept of system, or simply study ecosystems without attempting to define it, which given that the concept itself is a metaphor originated in a very different field, can be problematic.

Nevertheless, the concept of innovation ecosystem has merits that should not be overlooked. This is the case of its added emphasis on the interdependency between actors and organizations, which supports a more holistic view of the process of (social) innovation in a given institutional context (Ritala \& Almpanopoulou, 2017) while allowing for, at the same time, to account for the contributions and hindrances that the process of SI face at multiple levels, for different reasons. In this sense, innovation ecosystem draws heavily upon complex systems theory, as it is made of many interconnected and dependent components that interact with each other and collectively (Phillips \& Ritala, 2019).

Recently, Granstrand and Holgersson (2019: 3) proposed a more comprehensive definition that broadened the scope of the concept to better accommodate for different kinds of innovation, understanding innovation ecosystems as "the evolving set of actors, activities, and artifacts, and the institutions and relations, including complementary and substitute relations, that are important for the innovative performance of an actor or a population of actors."

Taking into consideration what was previously established about SI, understanding the SIE as a complex adaptive system, we suggest a definition that attributes importance to the several aspects discussed in this article: A social innovation ecosystem is the evolving meso-level environment created by non-market and market interactions of collectives of heterogeneous components, actors and institutions, with different roles and complementarities, that develop linkages to generate innovative answers to explicit or latent social needs, restructuring social and power relations and inducing social change.

Establishing a SIE requires: a mode of governance that integrates actors from civil society and the social, economic and academic field; SI hubs, labs and transfer centers, as intermediaries that accelerate SI activities; and the integration of different modes of innovation in transformational innovation strategies (Terstriep, Rehfeld \& Kleverbeck, 2020). SIEs are not homogeneous and different types do exist. Pel, Wittmayer, Dorland and Jørgensen (2019) suggested five types of SIE (the 'SI machine', the 'thin' ecosystem, the discursive field/SI memes, the local co-creation Hub, the political movement) that move between the dilemma of SI agency of 'innovation heroes' and the more structural characteristics of 'ecosystems'.

\section{The Social Innovation Ecosystem in Portugal}

\subsection{Methodology}

The research is based in semi-structured interviews with twenty-two strategic stakeholders that operate within the field of SI. These were researchers, directors of organizations that operate and assist in the sector, as well as social entrepreneurs, that were chosen for their prominent role in the Portuguese SIE. The criteria employed in the selection of the interviewees focused on the dimension and type of organizations that they represented, in an attempt to assure a high level of diversity and heterogeneity. Availability and convenience were also relevant criteria, although to a lesser extent. 
The average length of the interviews was 1 hour and 45 minutes. The recordings of these interviews were fully transcribed and analyzed to highlight potentially relevant themes for future research. The textual information from the interviews was carefully scrutinized in order to identify recurring subjects and themes. This serves as to familiarize the researchers with transcripts as a whole, before proceeding to the next steps that involve reducing information (i.e. selecting what is deemed relevant to the research) and identifying themes (Creswell \& Poth, 2018). After that, a referential content analysis was employed, which is a qualitative approach to content analysis, allowing for a deeper understanding of how actors, actions and events are portrayed and perceived by individuals (Franzosi, 2009). This was done to highlight the most important issues (Perakyla \& Ruusuvuori, 2017), while reducing the amount available data, in order to be more manageable, in turn facilitating the process of creating categories (Margolis \& Zunjarwad, 2017).

The approach to map the ecosystem is inspired by Bloom \& Dees (2008), considering the need to identify players and environmental conditions. We were particularly interested in the understandings of the interviewed actors about the ecosystem. First, it was consolidated, from the content analysis, the main perspectives about the ecosystems' characteristics in Portugal. Second, extracts that described the interviewees thoughts about the difficulties of working in the SIE and how that experienced changed in the last few years, following the legislation change and more recent financing programs that exclude some legal forms of organizations. These excerpts, while giving insight into the key-actors point of view and relating it to the context, try to highlight a coherent narrative about the transformation in the ecosystem and how this affected social enterprises.

\subsection{The Portuguese Social Innovation Ecosystem}

The Portuguese SIE has become more important to the national economy over the last few years and encompasses several types of organizations. The organizations that it encompasses have worked with the State in assuring the provision of welfare services, both during the late monarchy days in the XIX century and before the democratic revolution of 1974 (Garrido \& Pereira, 2018). This is more so the case of older legal forms, such as mercy houses, charitable foundations, social cooperatives and welfare associations, which became more important after 1974 , working closely with the State to assure the provision of welfare services to the population. These organizations gained a renewed interest in the aftermath of the 2007/2008 crisis, due to political attention devoted to the social and solidary economy and the cutbacks on public spending and social services in general dictated by the financial assistance programme negotiated with the European Central Bank, International Monetary Fund and European Commission.

Recent data divulged by the Satellite Account of the Social Economy (INE/CASES, 2019) shows that the social economy sector, in 2016, represented 3\% of the Portuguese Gross Value Added (GVA), 5.3\% of remunerations and total jobs and $6.1 \%$ of paid jobs. The report also highlights that there was an increase of $17.3 \%$ in the number of entities that comprise the Social Economy sector in relation to 2013, as well as increases in GVA (14.6\%), total jobs (8.5\%) and paid jobs $(8.8 \%)$. These values grew above the national average during this period and show a clear positive evolution and its importance to the economy, despite the cries that the solidarity sector is in financial trouble. Health and social services were the largest contributors to these results, representing $48.9 \%$ of the sector's GVA. Education follows as a distant third, representing $13.9 \%$. 
Table 1. Types of Organizations in the SSE in Portugal.

\begin{tabular}{|c|c|c|c|c|c|c|}
\hline \multirow[t]{2}{*}{ Types of entities } & Units & $\begin{array}{c}\text { Remunerated } \\
\text { jobs }\end{array}$ & GVA & Remuneration & $\begin{array}{l}\text { GVA/ } \\
\text { FTE }\end{array}$ & $\begin{array}{l}\text { Average } \\
\text { income }\end{array}$ \\
\hline & № & ECT & $10^{3}$ Euros & $10^{3}$ Euros & \multicolumn{2}{|c|}{$\begin{array}{c}10^{3} \text { Euros per } \\
\text { remunerated } \\
\text { FTE }\end{array}$} \\
\hline Cooperatives & 2343 & 24402 & 604241 & 572240 & 24.8 & 23.5 \\
\hline $\begin{array}{l}\text { Mutualist } \\
\text { associations }\end{array}$ & 97 & 4842 & 387971 & 212094 & 80.1 & 43.8 \\
\hline Mercy houses & 387 & 39445 & 596630 & 555267 & 15.1 & 14.1 \\
\hline Foundations & 619 & 14113 & 332321 & 304296 & 23.5 & 21.6 \\
\hline $\begin{array}{l}\text { Community and } \\
\text { self-managed } \\
\text { subsectors }\end{array}$ & 1678 & 305 & 1174 & 3795 & 3.9 & 12.4 \\
\hline $\begin{array}{l}\text { Associations with } \\
\text { altruistic ends }\end{array}$ & 66761 & 151779 & 2896871 & 2673894 & 19.1 & 17.6 \\
\hline Social economy & 71885 & 234886 & 4819210 & 4321587 & 20.5 & 18.4 \\
\hline National economy & - & 3839523 & $\begin{array}{c}162226 \\
133\end{array}$ & 81854147 & 42.3 & 21.3 \\
\hline $\begin{array}{c}\% \text { of the national } \\
\text { economy }\end{array}$ & - & $6.1 \%$ & $3.0 \%$ & $5.3 \%$ & $48.6 \%$ & $86.3 \%$ \\
\hline
\end{tabular}

Source: INE (2019).

It should be noted that understandings of social economy, social enterprises and social entrepreneurs vary greatly across countries, even if the western European countries do have many similarities to them (Kerlin, 2006; Defourny \& Nyssens, 2017). While there are fundamental differences between the concepts, we discuss them as a whole in this article, drawing attention to specific sectors or legal forms when relevant. We use the SIE designation as a broad, generic category for social organizations, as to avoid confusion between the formal social economy sector (which is legally defined in Portugal) and the social sector as a whole (Osborne, 2008). Definitions tend to be grounded in specific empirical realities that not always translate well into cross-country comparisons (Lee, 2015), with these particularities resulting from historical differences, which is precisely the Portuguese case.

\subsection{Variety of Social Enterprises in Portugal}

Social enterprises are not defined solely by what services they offer, nor by their mission. Some enterprises were created to address specific problems of their community, while others use their revenues to support social missions. This means that profit/return generation is not so much an end in itself, but rather a means to an end (Lee, 2015). The same logic applies to social entrepreneurs, who are not so much interested in financial profits: "Social entrepreneurs are seen as individuals/organizations who catalyze social change and address important social needs in innovative ways, but with a relatively higher priority given to promoting social value and development rather than capturing financial benefit" (Lee, 2015: 271).

If it is somewhat easy to explain what social enterprises do, it is quite harder to define them, since definitions are frequently grounded on what a specific set of social enterprises do or where they are located. Borzaga et al. (2020: 26) in their comparative report on SE across Europe, for example, distinguish between two major definitions, i.e., "organizational definitions, focusing on intrinsic features that social enterprises show" and "sector-specific definitions, looking only at specific types of organizations". Also problematic is the fact that social businesses, community 
enterprises, social ventures or social-purpose businesses are used interchangeably with social enterprises (Lee, 2015), fragmenting the empirical and theoretical knowledge produced about the subject, as it was the case with SI - a trend that appears to be ever-present in this field of research, one might add.

This article draws upon the Social Business Initiative (SBI) of 2011, promoted by the EU, as the basis for our conceptualization of social enterprises. The SBI specified three key characteristics that define a social enterprise, namely: a) the primary objective being the achievement of social impact rather than the generation of profit reverting to owners or shareholders; $b$ ) the existing surpluses are employed towards the desired social goals; c) the management of said enterprises is both innovative and transparent, involving workers, customers and stakeholders in the process (cf. Ferreira, 2019).

Research on social enterprises in Portugal has taken place since the year 2000, mostly in the framework of international research projects. A recently published European Commission study - Social Enterprises and their Ecosystems in Europe (Ferreira, 2019) -, found that the intervention areas of the Portuguese social enterprises were diverse and worked mostly in social assistance. These social enterprises work in areas such as protected employment and professional education targeting vulnerable groups, social and health services, as well as education (infant education through high school). The study concluded that most of these interventions correspond to the non-profit entrepreneur model, social cooperatives and social insertions enterprises, with Private Institutions of Social Solidarity - a specific status for welfare organizations awarded by the State - and social solidarity cooperatives being predominant.

Subsequent research (Ferreira \& Almeida, 2020) ${ }^{1}$ identified the variety of social enterprises in Portugal: five models, each with their specific discourses, social actors, privileged legal forms and frameworks, boundaries and industry fields: i) the entrepreneurial non-profit model, ii) the work integration social enterprise model, iii) the social cooperative model iv) the social solidarity social enterprise model and the $\mathrm{v}$ ) and the more recent, widely EU driven social business model. Whereas models $i$ to iv can be described inside the social economy, model $v$ tends to spill over the social economy.

\subsection{The Social Innovation Ecosystem in Portugal}

The content analysis of the interviews indicates that the Portuguese SIE is characterized by the existence of three very different and somewhat disconnected sub-ecosystems, from which different social enterprise models emerge, with trajectories shaped by the differing dynamics of these ecosystems. These sub-ecosystems are designated as the social economy ecosystem, the social business ecosystem, and the social solidarity ecosystem. A Venn diagram (Figure 1) illustrates the relative weight, proximities and overlapping areas in the sub-ecosystems.

The social economy ecosystem is the one with the strongest expression, followed by the social business as a distant second, and the social solidarity ecosystem. Drawing from literature review and documental analysis, different social enterprise models were identified (Ferreira \& Almeida, 2020) and can be located within each of these ecosystems. The social economy ecosystem is mostly comprised of social cooperatives and social and solidarity economy enterprises. The social solidarity ecosystem encompasses entrepreneurial nonprofit model as well as the work integration social enterprises, and in the newer social business ecosystem we find the social business model.

\footnotetext{
${ }^{1}$ Research carried out in the context of TIMES, focusing the meaning, profile, institutional context and roles of social enterprises in Portugal (please cf. Ferreira et al. (2021). This project is connected to the conceptual and methodological proposals of ICSEM - International Comparative Social Enterprise Models, and with the COST Action EMPOWER-SE - Empowering the Next Generation of Social Enterprise Scholars.
} 
Figure 1. Portuguese Social Innovation Ecosystem and Sub-ecosystems.

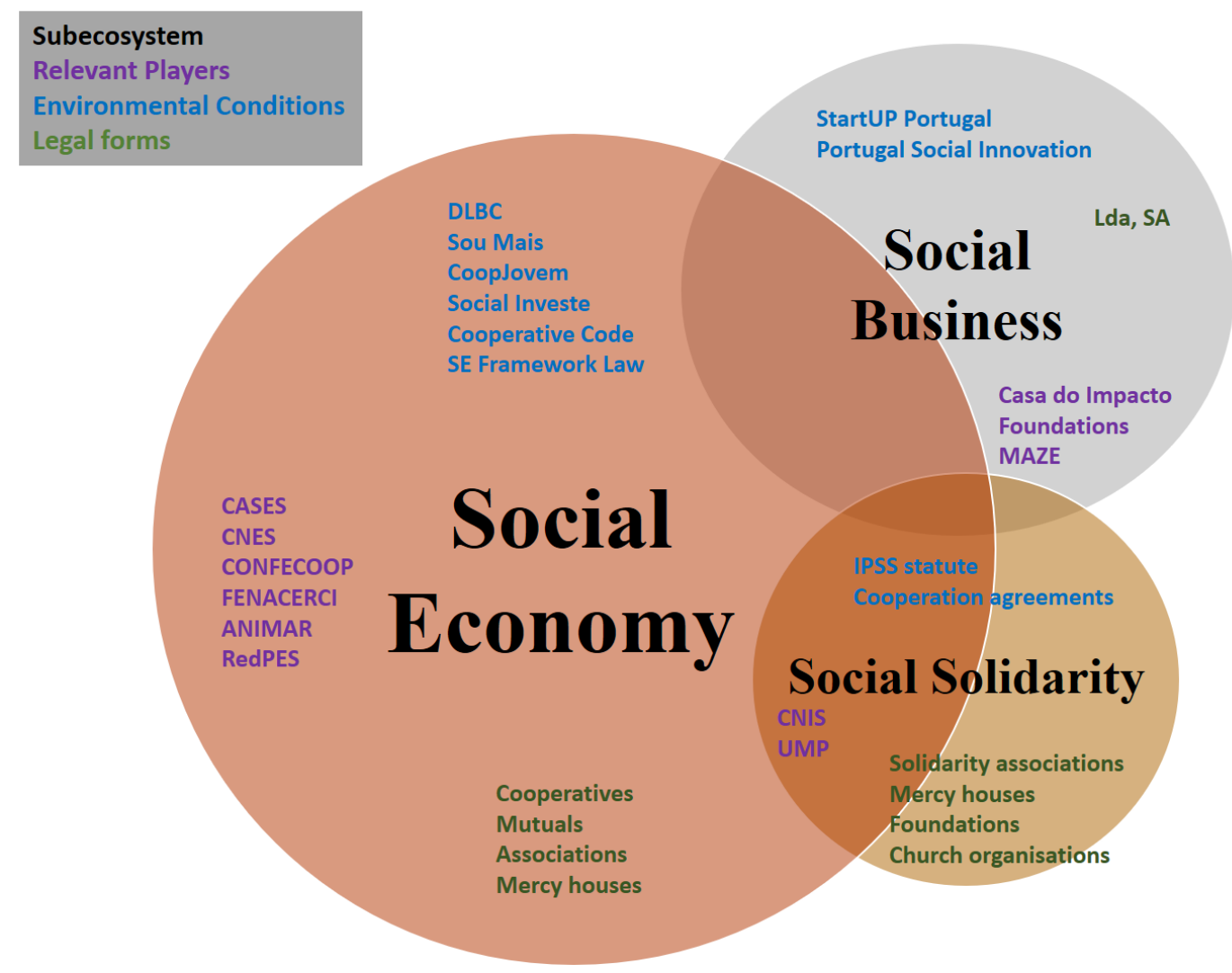

Source: Authors' elaboration.

The 'social economy ecosystem' size should not be a surprise, given how it is comprised by the most common and important organization types: cooperatives, associations, mutualist associations and mercy houses. This also shows the variety of legal forms that exist in this subsector, which, in turn, partly explains the difficulty of creating financing programs, credit lines and specific legislation for the sector, as the interviews show. This ecosystem is enhanced by the relatively recent structuration of the social economy around a set of principles and legal forms defined in the Framework Law of the Social Economy (Almeida \& Albuquerque, 2020), enhanced by the main body in charge of developing the sector, CASES - António Sérgio Cooperative for the Social Economy, and a voice in government through the National Council of the Social Economy.

Several support programmes for the social economy are managed by CASES such as the microcredit program Sou Mais and Social Investe or the cooperative entrepreneurship program CoopJovem. Within this ecosystem, the social cooperative and the social solidarity enterprise models are prominent. It rests in the setting up of multi-stakeholder cooperatives for people with disabilities and evolved for a specific social cooperative branch, represented by the umbrella FENACERCI and it emphasizes the entrepreneurial dimension of cooperatives, the aim of social integration as expression of social citizenship rights, and participation of all stakeholders in governance.

The 'solidarity economy social enterprise' model comprises diverse organizations, founded since the 1990s and includes local territorial development-oriented organizations that make use of EU funded projects for rural and disadvantaged areas and publics (Moreno, 2003; Amaro, 2009). More recently, they were joined by new types of organizations, mostly cooperatives, created around concerns related to local and sustainable development and environmental protection, articulated with the willingness to doing economic activity differently and in service 
of local communities, with a strong emphasis on stakeholders' participation. The two main networks organizing these players are ANIMAR and the Portuguese Network for the Solidarity Economy (RedPES).

The 'social business ecosystem' is the second-largest subsystem, being closer in terms of relevance to the smaller social solidarity than the social economy ecosystem. It mostly comprises enterprises and philanthropic foundations interested in SI and impact investment. Social businesses only recently gained traction in the sector and are becoming more prevalent. They greatly benefit from favorable legislation and programmes, since other legal forms are sometimes excluded from specific financing programs and have restrictions on the activities and services offered, while the legal forms of commercial enterprises are more flexible, being able to adapt more quickly and diversity their activities.

The 'social business model' is influenced by international and European frameworks and structured nationally around new actors such as business schools, consultants, foundations and some public policies. This social enterprise model is often associated to the idea that the commercial form may be the more adequate legal form as long as it balances social and market goals. Several initiatives carried out by consultants, business schools, foundations and support organizations have tried to foster social businesses in light of the adoption of EU frameworks on SI and social entrepreneurship (e.g., Social Business Initiative).

The 'social solidarity ecosystem' has the smallest weight of the three subsystems and includes the entrepreneurial non-profits and the work integration social enterprises. While the IPSS (Instituições Particulares de Solidariedade Social) designation dates back to 1983, some of the legal forms included in this sub-ecosystem are centuries old, such as the charitable foundations, mercy houses and church organizations, having played a key role in the provision of welfare services since the XIX century, and represented by federative bodies such as the social solidarity institutions (CNIS), the mutuals unions (UMP and APM) and the mercy houses union (UPM). With the democratic revolution of 1974, these organizations grew in number and today there are close to five thousand registered IPSS (Ferreira, 2019). These organizations have cooperation agreements with the welfare administration which are stable quasi-contracts. However, they are also underfunded and struggle to assure the viability of their operations. This has been accentuated as of late, given the tendency of the Portuguese State to reduce costs with social expenses, with many offering paid services and developing commercial relations in order to finance their social work, even if they are not part of their core function (Guerreiro \& Pinto, 2021).

The work integration social enterprises exist mostly within this ecosystem as they are most often related IPSS. Sheltered Employment Centers are adapted units of production created by public, private or cooperative organizations aiming at providing access to paid work by people with disability. Social Insertion Enterprises were enterprises dependent on public funding and mostly managed by non-profit organizations and social cooperatives, usually without a legal form. They were created by public policy, under a top-down logic, in 1996, to promote the employment of socially vulnerable groups, legally limited to certain areas of activity, less attractive to the market, since they should not be competing with for-profit organizations. Since the extinction of this program in 2015, only a few became independent organizations and others became services in non-profit organizations.

It should be noted that there is very limited overlap between the different sub-ecosystems, especially between social business and social solidarity. This can be explained by the relative novelty of social enterprises, as well as by the more substantial differences in their ecosystems. However, some social solidarity organizations and elements of their SIE are becoming oriented to the social business framework and model. The social economy sub-ecosystem has a greater overlap with the other sub-ecosystems, given both the tradition associated to the cooperative sector, and the recent policy activism around the concept of social economy, with the convergence of both the cooperative and the charitable traditions - eg., CASES includes both the cooperative 
and local development federative bodies as well as those of IPSS. While the social business ecosystem is more recent, its resonance in the strategic actors and policies - such as Portugal Social Innovation - is becoming significant. This shows that this sub-ecosystem is growing fast and is a crucial component of the recent trend in SI.

\subsection{Strategic Actors' Perspectives on the Social Innovation Ecosystem}

The traditionally fragmented landscape that characterizes the third sector did not vanish with the effort to develop a SIE. During the interviews, several aspects were raised regarding the possibilities for the SIE to develop.

One of the key issues is the lack of density and few actors populating this ecosystem:

The development of social enterprises depends on the actual social enterprises, with a more favorable ecosystem from a legal, institutional and cognitive point of view ... And it requires through a fundamental idea that they have to cooperate with each other. (E2, Director of a Financial Cooperative).

Whereas the stakeholders from the social solidarity ecosystem are seen by social economy stakeholders as maintaining a distant and parallel ecosystem, very reluctant to enter in a collective SIE dynamics.

[Some organizations are] here but not of their own decision. They were almost forced to.

There is a risk in creating this: either we can move on from this sentiment and manage to work together, or they will remain being forced to work with us and it will be a formal collaboration only. (E2, Director of a Financial Cooperative).

Not all types of stakeholders are comfortable in the new emphasis given to SI. For the cooperatives, the recent years have been disempowering. During the crisis, and the structural adjustment promoted by the EU Central Bank, the IMF and the European Commission, cooperatives lost some fiscal benefits and have more difficulty accessing EU funding targeted for enterprises, given that cooperatives are not eligible. As one stakeholder indicates, the Cooperative Code limits their activities by restraining them to specific branches where they are registered, creating an unequal situation with commercial enterprises. Stakeholders from the cooperative sector identified some loss of identity, support and autonomy of their sector, in the name of the SIE development.

...we lost our previous statute, which was a differentiated statute with financial benefits... we had an institute solely for the cooperative sector, specialized programmes for the cooperative sector. And all that has been lost. I am not saying that this is bad, because we ended up being in the right place, which is in the big social economy family. (E1, Vice-President of a National Federation of Cooperatives).

Despite improvements in terms of registration procedures for cooperatives (e.g., Cooperativa na hora), it is easier to set up a commercial business than a cooperative. The pressure towards market isomorphism is present, as exemplified in the change of the Cooperative Code to allow investor-members and creating the possibility that in some cooperatives' members vote may vary according to capital.

[We are not a cooperative] because, from the bureaucratic, fiscal point of view it is a lot heavier and more complicated and, in the last few years, the associative statute allows us, for example, to access applications that a cooperative statute would difficult. Until this day, it has never been justified having that work. (E4, Director of an Association).

Access to funding is problem in the SIE, especially for smaller scale organizations, that do not fulfil requirements for having access to EU funding.

Innovation is done through EU programs, but some of them are not accessible to cooperatives, or at least to some cooperatives that have an entrepreneurial dimension, and not any other kind of condition to developed. Often, to develop a project, I have to guarantee with my personal bank account, in order to receive funding, or otherwise I'm 
not paid and not all cooperatives have this possibility. (E1, Vice-President of a National Federation of Cooperatives).

This is in fact agreed by many of the interviewed stakeholders in the SIE, in the sense that this policy is targeting very specific initiatives which can be of interest for investors with the capacity to generate financial return and an organizational form where investors can participate. Among the issues raised, in the social solidarity organizations, the relationship with public agencies creates doubts. Stakeholders claim that the State is not complying with its part in the funding. On the other hand, the new program Portugal Inovação Social is not seen by some stakeholders in the social economy sub-ecosystem as oriented towards these organizations.

Who is being financed by PIS at this moment? [...] There were social projects' funds with millions of Euros that just stood there. Where was all this money (...) Why didn't it reach the entities who need it daily to pay their bills and manage social projects that minimize the effects of the crisis, that created job opportunities, prevented families and firms from going into bankruptcy, or that assisted several families and firms that actually went into bankruptcy? So, where is this money? (E5, Coordinator of a Cooperative).

This funding-centered (subsidized) approach is also heavily criticized by the social business ecosystem actors. It is crucial for the ecosystem consolidation to mitigate these tensions among different sub-ecosystems actors, but that may be difficult to achieve.

We may radicalize the two groups. The group of the youngest social entrepreneurs that is of the social business and the group of the more traditional social sector. In the more traditional social sector there is a terrible fear that there will be an invasion of capitalist models within their sector. In the entrepreneurial sector there is great ignorance about what the traditional social sector is. And so, the problem is fear on the one hand and ignorance on the other. And what we are trying to do is to slowly, delicately, create points of contact here and there. But this is a slow process and it has to have a different policy contribution. (E7, Coordination of PIS).

The underfunding of the SIE in Portugal is known in government spheres, even if the recent changes to funding policies have had debatable results. But the management of social projects has also been an issue, especially given the growing complexity of both national and EU programs. Organizations often lack the structure or means to implement projects, even when the funding is assured. PIS was designed with this in mind, as it promotes private investment in SI and social entrepreneurship projects:

$150 €$ million were channeled towards this mission, in the form of four financing instruments. These four instruments were created with two premises in their design. The first premise is that each of them is oriented towards a specific development phase of the social innovation project. It follows what is, in principle, the life cycle of a social innovation or social entrepreneurship project. The second premise is that they all assume the development of partnerships between social organizations and the public or private investors dependent of the financing line. (E7, Coordination of PIS).

It is troubling that the concepts that guide these national programs are often murky or not defined at all, a fact admitted by officials that manage said programs. They often do not know how some understandings of what social enterprises are or who is illegible for what programs or financing lines. It is suspected that many problems derive from the acritical usage of older definitions that remain in the official documents that guide and applications to these programs, which in turn hinder the process.

I think that, from the point of view of the promotion of social and solidary economy, there would be advantages in a unified and clear policy, because the current one is very fragmented between cooperatives, IPSSs and foundations... from a political standpoint, everything is still very fragmented and none of this helps and once again we remain riddled with corporations inside the social economy... nothing helps. (E4, Director of an Association). 
Still, PIS as well as other initiatives have proven themselves important in moving the SIE forward, even with all their shortcomings.

When [my institute] was born in 2008, social innovation wasn't even discussed. Today there are social investors, enterprises that are ever more worried with impact, not only because of the ecosystem development, but because of societal pressures... 92\% of collaborators, mostly millennials, want to have impact as a result of their work, want a purpose, and that influences organizations (...) I think that there is a tendency of the society and the national ecosystem evolved greatly. I think the IES had an important role, but PIS had a fundamental role, the creation of the social investment market had a very important role and all these things helped the discussion to evolve to a whole different level. (E8, President of the Board of a Social Business School).

\section{Conclusions}

The metaphor of ecosystem was explored in this article to underline the creation of a new type of complex, systemic and evolving group of collectives of heterogeneous components, actors and institutions, with varied roles and complementarities, in the Portuguese SI landscape. We underlined that SI aims at creating innovative answers to explicit or latent social needs, restructuring social and power relations and inducing social change and that it was adopted by Portuguese public institutions in order to restructure the social economy sector and how it operates. In a moment when complex wicked problems characterize contemporary society, it is particularly relevant to understand reality using definitions and methods that take into account the existing complexity, more so than using abstract concepts without fully understanding how they will translate into practice and affect the everyday life of organizations.

We use the SIE metaphor to highlight relevant aspects of the evolution of the SI landscape and to illustrate the emergence and connections of new sub-systems. The Portuguese SI landscape has changed a great deal over the last few years but it is too soon to refer that a robust SIE exists at all. Three different sub-systems remain disconnected as the main driving forces of the ecosystem. Much of the social economy sector was anchored in organizations and legal forms that dated back decades and only during the post 2008 crisis period the debate around SI and social economy was seriously discussed by political actors (Garrido \& Pereira, 2018). Still, the definition of many concepts remains unclear in the national legislation and programs, and this is the root of the problems related to the eligibility of some legal forms for financing lines, as the efforts to properly relate the scientific concepts to the legal requirements and necessities of the social economy organizations were not successful.

This is ever more so the case when one considers the variety of traditions and legal forms of social organizations operating in the country and how programs such as the Portugal Inovação Social create disparities in terms of eligibility and legal frameworks fail to deliver all social enterprises the same development opportunities, fostering an environment in which these organizations compete with each other or are outright excluded from financing lines because of their legal forms, something that comes as a surprise for organizations that have been financed for providing social services for decades.

There is a growing concern that the attention given to the SIE attests the diminishing role of the state in the promotion of welfare, relying instead on social entrepreneurship and social businesses to perform these services, a trend that has been described as neoliberal in principle (Pel et al., 2019) and the prominence given to the market tools as ecological dominance (Luhmann, 1974). On the other hand, the fact that the welfare state lacks the resources to maintain high standards of the social services offered is undeniable and inevitable, which has motivated governments and institutions to look for alternate means of assuring that these services are accessible (Kerlin, 2006).

Still, the potential of the SI cannot be denied and no matter what stance one assumes about the subject, developing a robust SIE will play a major role in the quality of responses to social 
needs in the years to come. And while public policy has much to catch up with in terms of concepts, methods and procedures, it has shown signs of improvement and openness to adapt to the new paradigm of SI in the promotion of positive social change.

In the perspective of interviewees, the Portuguese SIE suffers from a lack of enabling policies that foster SI and empowers both organizations and citizens in promoting social change. The stakeholders regret the difficulty in establishing dialogue and communication lines with institutions and policymakers, who work in a more abstract level, too far from the day-to-day operations of social organizations to fully grasp the complexity of their activities when also faced with ever more complex legal requirements to ensure funding.

The stakeholders also hold the belief that the SIE will become more important in the following years, an argument supported by the growing GVA that official statistics present (INE, 2019). While Portuguese economy is doing better than in pre-crisis years, inequalities and social issues have proven persistent and show no signs of significant improvements and social organizations are expected to complement the state in providing social welfare services, answer unmet needs and tackle complex social problems.

From this perspective, the emergence of SI has not been as successful, given that it created new untimely challenges that these organizations have to deal with. While perceived as wellmeant by several interviewees, the compulsory nature of the Portuguese legislation and funding guidelines make it so that SI is a means to an end rather than an end in itself. This is made apparent by the lack of understanding of social innovation shown by some documents and legal requirements that overfocus the formal dimension of the processes, rather than the social change social innovation promises.

These findings and considerations serve as a cautionary tale for the application and adoption of social innovation as a social policy design. While it is difficult to say that Portugal enacted profound changes too fast for the social organizations to keep up with, it is clear from the stakeholder's perspectives that there were considerable issues in terms of planning, as several legal and programmatic changes were not accounted. Several social organizations were left without funding and because of that, as not all forms were eligible for funding, which can be seen as disconcerting, as it appears that the State is choosing what kind of organizations it wants to fund based not on their results and performances, but rather on their legal form.

\section{Acknowledgements}

This article is based in the TIMES - Institutional Trajectories and Social Enterprise Models in Portugal, project financed by the European Regional Development Fund through COMPETE 2020 - Competitiveness and Internationalization Operational Program (POCI) and by Portuguese funds through the FCT - Foundation for Science and Technology (ref. PTDC/SOCSOC/30612/2017 I POCI-01-0145-FEDER-030612). Hugo Pinto is supported by the FCT (DL57/2016/CP1341/CT0013).

\section{References}

Adner, R. (2006). Match Your Innovation Strategy to Your Innovation Ecosystem. Harvard Business Review, $84,98-110$.

Almeida, C.D., \& Albuquerque, C.M. (2020). Welfare State in Portugal: delegated powers or disclaims responsibility? GIGAPP Estudios Working Papers, 147(7), 141-157.

Amaro, R.R. (2009). Economia Solidária da Macaronésia - Um Novo Conceito. Revista de Economia Solidária: Economia Solidária - Apresentação do Conceito. Ponta Delgada, 1, 11-28. 
André, I., \& Abreu, A. (2006). Dimensões e Espaços da Inovação Social. Finisterra, 41(81), 121-141. https://doi.org/10.18055/Finis1465

Asenova, D., \& Damianova, Z. (2019). The Interplay Between Social Innovation and Sustainability in the CASI and other FP7 Projects. In J. Howaldt, C. Kaletka, A. Schroder M. \& M. Zirngiebl (Eds.), Atlas of Social Innovation: new practices for a better future (pp. 44-47). SI Drive.

Ayob, N., Teasdale, S., \& Fagan, K. (2016). How Social Innovation 'Came to Be': Tracing the Evolution of a Contested Concept, Journal of Social Policy, 45(4), 635-653. https://doi.org/10.1017/S004727941600009X

Bertalanffy, L.V. (1968). General Systems Theory: Foundations, Development, Applications. George Braziller. Bloom, P., \& Dees, J.G. (2008). Cultivate Your Ecosystem. Stanford Social Innovation Review, 6, 46-53.

Borzillo, S., \& Kaminska-Labbe, R. (2011). Unravelling the dynamics of knowledge creation in communities of practice through complexity theory lenses. Knowledge Management Research $\mathcal{E}$ Practice, 9, 353-366. https://doi.org/10.1057/kmrp.2011.13

Bristow, G., \& Healy, A. (2018). Innovation and regional economic resilience: an exploratory analysis, The Annals of Regional Science, 60, 265-284. https://doi.org/10.1007/s00168-017-0841-6

Cairney, P., \& Geyer, R. (2017). A critical Discussion of Complexity Theory: How does 'Complexity Thinking' improve our Understanding of Politics and Policymaking? Complexity, Governance E Networks, 3(2), 1-11. https://doi.org/10.20377/cgn-56

Cajaiba-Santana, G. (2013). Social Innovation: Moving the Field Forward. A conceptual framework, Technological Forecasting \& Social Change, 82, 42-51. https://doi.org/10.1016/j.techfore.2013.05.008

Campbell-Hunt, C. (2007). Complexity in practice. Human Relations, 60(5), 793-823. https://doi.org/10.1177/0018726707079202

Castellani, B., \& Hafferty, F. (2009). Sociology and Complexity Science: A New Field of Inquiry. Springer.

Cooke, P. (2012). Complex Adaptive Innovation Systems. Routledge.

Creswell, J.W., \& Poth, C.N. (2018). Qualitative Inquire E Research Design. Sage Publications.

Defourny, J., \& Nyssens, M. (2017). Mapping social enterprise models: some evidences from the "ICSEM" project, Social Enterprise Journal, 13(4), 318-28. https://doi.org/10.1108/SEJ-09-2017-0049

Durst, S., \& Poutanen, P. (2013). Success factors of innovation ecosystems - Initial insights from a literature review. In R. Smeds \& O. Irrmann (Eds.), CO-CREATE 2013: The Boundary-Crossing Conference on Co-design in Innovation (pp. 27-38). Aalto.

Ferreira, S., Fidalgo, P., Giovannini, M., Almeida, J., Pinto, H., Lima, T. M., ... \& Ferreira, V. (2021). Trajetórias Institucionais e Modelos de Empresa Social em Portugal, Centro de Estudos Sociais: Coimbra, Available at: https:/estudogeral.sib.uc.pt/bitstream/10316/96549/3/e-book\%20TIMES.pdf

Ferreira, S., \& Almeida, J. (2020). Social Enterprises in Portugal: Concepts, contexts and models. In J. Defourny \& M. Nyssens (Eds.), Social Enterprise in western Europe (pp. 182-189). Routledge.

Ferreira, S. (2019). Social Enterprises and their Ecosystems in Europe: Country Report Portugal. Publications Office of the European Union.

Floysand, A., \& Jakobsen, S. (2010). The Complexity of Innovation: a relational turn, Progress in Human Geography, 35(3), 328-344. https://doi.org/10.1177/0309132510376257 
Franzosi, R.P. (2009). Content Analysis. In M. Hardy \& A. Bryman (Eds.), The Handbook of Data Analysis (pp. 547-565). Sage Publications.

Frenken, K. (2017). A Complexity-Theoretic Perspective on Innovation Policy. Complexity, Governance $\mathcal{E}$ Networks, 35-47. https://doi.org/10.20377/cgn-41

Garmestani, A.; Allen, C., \& Gunderson, L. (2009). Panarchy: Discontinuities Reveal Similarities in the Dynamic System Structure of Ecological and Social Systems. Ecology and Society, 14(1), 15. http://www.ecologyandsociety.org/vol14/iss1/art15/

Garrido, Á., \& Pereira, D. (2018). A Economia Social em Movimento: uma história das organizações. Tinta da China.

Godin, B. (2012). Social Innovation: Utopias of Innovation from c.1830 to the Present. Project on the Intellectual History of Innovation Working Paper 11, 1-52.

Godin, B. (2015). Innovation Contested: The Idea of Innovation over the Centuries. Routledge.

Gomes, L.A.V., Facin, A.L.F., Salerno, M.S., \& Ikenami, R.K. (2018). Unpacking the innovation ecosystem construct: Evolution, gaps and trends, Technological Forecasting \& Social Change, 136, 30-48.

Granstrand, O., \& Holgersson, M. (2019). Innovation ecosystems: A conceptual review and a new definition, Technovation, 90, 102098. https://doi.org/10.1016/j.technovation.2019.102098

Guerreiro, J.A., \& Pinto, H. (2021). Social Innovation, Fourth Sector and the Commodification of the Welfare State: The Portuguese Experience. In M.I. Sánchez-Hernández, L. Carvalho, C. Rego, M. R. Lucas \& A. BackxNoronha (Eds.), Entrepreneurship Trends in the Fourth Sector. Looking for sustainable development. Springer.

Habermas, J. (1986). The New Obscurity: the crisis of the welfare state and the exhaustion of utopian energies. Philosophy \& Social Criticism, 11(2), 1-18. https://doi.org/10.1177/019145378601100201

INE. (2019). Conta Satélite da Economia Social - 2016. Available at: https://www.ine.pt/ngt_server/attachfileu.jsp?look_parentBoui=382482927\&att_display=n\&att_download= y

Kallemeyn, L., Hall, J., \& Gates, E. (2020). Exploring the Relevance of Complexity Theory for Mixed Methods Research. Journal of Mixed Methods Research, 14(3), 288-304. https://doi.org/10.1177/1558689819872423

Kerlin, J.A. (2006). Social Enterprises in the United States and Europe: Understanding and Learning from the Differences. Voluntas, 17, 247-63.

Lee, I. (2015). A Social Enterprise Business Model for Social Entrepreneurs: theoretical foundations and model development, International Journal of Social Entrepreneurship and Innovation, 3(4), 269-301.

Luhmann, N. (1995). Social Systems. Stanford University Press.

Luhmann, N. (1974). Grundrechte als Institution. Ein Beitrag zur politischen Soziologie. Duncker \& Humblot.

Margolis, E., \& Zunjarwad, R. (2017). Visual Research. In N. Denzin \& Y. Lincoln (Eds.), The Sage Handbook of Qualitative Research (pp. 1039-1089). Sage Publications.

Martin, R., \& Sunley, P. (2010). Complexity thinking and evolutionary economic geography. In R. Boschma \& R. Martin (Eds.), The Handbook of Evolutionary Economic Geography (pp. 93-119). Edward Elgar.

McGowan, K., Westley, F., \& Tjornbo, O. (2017). The History of Social Innovation. In F. Westley, K. McGowan \& O. Tjornbo (Eds.), The Evolution of Social Innovation: Building Resilience Through Transitions (pp. 1-17). Edward Elgar Publishing. 
Moore, J.F. (1993). Predators \& Prey: A New Ecology of Competition. Harvard Business Review, 71, 75-86.

Moore, M., \& Westley, F. (2011). Surmountable Chasms: Networks and Social Innovation for Resilient Systems, Ecology and Society, 16(1), 5. http://www.ecologyandsociety.org/vol16/iss1/art5/

Moreno, L. (2003). Guia das organizações e iniciativas de desenvolvimento local. ANIMAR.

Moulaert, F., MacCallum, D., \& Hillier, J. (2013). Social innovation: intuition, precept, concept, theory and practice. In F. Moulaert, D. MacCallum, A. Mehmood \& A. Hamdouh (Eds.), The International Handbook on Social Innovation (pp. 13-24). Edward Elgar Publishing.

Moulaert, F., \& MacCallum, D. (2019). Advanced Introduction to Social Innovation. Edward Elgar Publishing.

Moulaert, F., MacCallum, D., \& Hillier, J. (2013). Social Innovation: Intuition, precept, concept, theory and practice. In F. Moulaert, D. MacCallum, A. Mehmood \& A. Hamdouch (Eds.), The International Handbook on Social Innovation: Collective Action, Social Learning and Transdisciplinary Research (pp. 13-24). Edward Elgar Publishing.

Nicholls, A., \& Ziegler, R. (2019). Creating Economic Space for Social Innovation. Oxford University Press.

Noya, A. (2011). The Essential Perspectives of Innovation: The OECD LEED Forum on Social Innovations. In OECD (Ed.), Fostering Innovation to Address Social Challenges Workshop Proceedings (pp. 18-24). OECD Publications.

Oh, D., Phillips, F., Park, S., \& Lee, E. (2016). Innovation ecosystems: A critical examination, Technovation, 54, 1-6. https://doi.org/10.1016/j.technovation.2016.02.004

Osborne, S.P. (2008). Key issues for the third sector in Europe. In S.P. Osborne (Ed.), The Third Sector in Europe: Prospects and challenges (pp. 3-6). Routledge.

Parsons, T. (1951). The Social System. Collier-MacMillan Limited.

Pel, B., Wittmayer, J., Dorland, J., \& Jørgensen, M.S. (2019). Unpacking the social innovation ecosystem: an empirically grounded typology of empowering network constellations. Innovation: The European Journal of Social Science Research, 33(3), 311-336. https://doi.org/10.1080/13511610.2019.1705147

Perakyla, A., \& Ruusuvuori, J. (2017). Analyzing Talk and Text. In N. Denzin \& Y. Lincoln (Eds.), The Sage Handbook of Qualitative Research (pp. 1163-1201). Sage Publications.

Phillips, M., \& Ritala, P. (2019). A complex adaptive systems agenda for ecosystem research methodology. Technological Forecasting $\mathcal{E}$ Social Change, 148, 119739 https://doi.org/10.1016/j.techfore.2019.119739

Richardson, K. (2004). Systems theory and complexity: Part 1. Emergence: Complexity and Organizations, 6(3), 75-79.

Ritala, P., \& Almpanopoulou, A. (2017). In defense of 'eco' in innovation ecosystem. Technovation, 60/61, 3942.

Russell, M., \& Smorodinskaya, N. (2018). Leveraging complexity for ecosystemic innovation. Technological Forecasting $\mathcal{E}$ Social Change, 136, 114-131. https://doi.org/10.1016/j.techfore.2017.11.024

Schneider, A. (2014). Embracing ambiguity - lessons from the study of corporate social responsibility throughout the rise and decline of the modern welfare state. Business Ethics: A European Review, 23(3), 293308. https://doi.org/10.1111/beer.12052

Shaw, D.R., \& Allen, T. (2018). Studying innovation ecosystems using ecology theory. Technological Forecasting E Social Change, 136, 88-102. https://doi.org/10.1016/j.techfore.2016.11.030 
Stichweh, R. (2011). Systems Theory. In B. Badie, D. Berg-Schlosser \& L. Morlino (Eds.), International Encyclopedia of Political Science (pp. 2579-2581). Sage.

Strasser, T., Kraker, J., \& Kemp, R. (2020). Three Dimensions of Transformative Impact and Capacity: A Conceptual Framework Applied in Social Innovation Practice. Sustainability, 12, 4742. https://doi.org/10.3390/su12114742

Tansley, A.G. (1935). The Use and Abuse of Vegetal Concepts and Terms, Ecology, 6(3), $284-307$. https://doi.org/10.1177/0309133307083297

Terstriep J., Rehfeld, D., \& Kleverbeck, M. (2020). Favourable social innovation ecosystem(s)? - An explorative approach. European Planning Studies, 28, (5), 881-905.

https://doi.org/10.1080/09654313.2019.1708868

Thomas, L., \& Autio, E. (2012). Modeling the ecosystem: a meta-synthesis of ecosystem and related literatures. Conference DRUID Working Paper, 1-40.

Thomas, L., \& Autio, E. (2020). Innovation ecosystems in management: An organizing typology. In Aldag (Ed.), Oxford Encyclopedia of Business and Management. Oxford University Press.

Turner, J., \& Baker, R (2019). Complexity Theory: An Overview with Potential Applications for the Social Sciences. Systems, 7(1), 4. https://doi.org/10.3390/systems7010004

Valkokari, K. (2015). Business, innovation, and knowledge ecosystems: how they differ and how to survive and thrive within them. Technology Innovation Management Review, 8(5), 17-24. http://doi.org/10.22215/timreview/919

Van Der Have, R., \& Rubalcaba, L. (2016). Social innovation research: An emerging area of innovation studies? Research Policy, 45(9), 923-1935. https://doi.org/10.1016/j.respol.2016.06.010

Vancouver, J.B. (2013). Systems Theory of Organizations. In E. Kessler (Ed.), Encyclopedia of Management Theory (pp. 815-820). Sage.

Williams, A. (2020). Political Hegemony and Social Complexity: Mechanisms of Power After Gramsci. Palgrave Macmillan.

Yawson, R.M. (2009). The Ecological System of Innovation: A New Architectural Framework for a Functional Evidence-Based Platform for Science and Innovation Policy. XXIV ISPIM 2009 Conference, The Future of Innovation, Vienna, Austria.

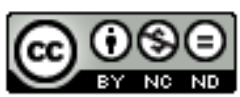

(C) Attribution-NonCommercial-NoDerivatives 4.0 International (CC BY-NC-ND 4.0)

https://creativecommons.org/licenses/by-nc-nd/4.0/ 